\title{
PEMANFAATAN PATI BIJI DURIAN (Durio zibethinus Murr.) DAN PATI SAGU (Metroxylon sp.) DALAM PEMBUATAN BIOPLASTIK
}

\section{(THE UTILIZATION OF DURIAN SEED STARCH (Durio zibethinus Murr.) AND SAGO STARCH (Metroxylon sp.) IN MAKING OF BIOPLASTIC)}

\author{
Melanie Cornelia ${ }^{1}$, Rizal Syarief $^{2}$, Hefni Effendi $^{3}$, Budi Nurtama $^{4}$ \\ ${ }^{1)}$ Doctoral Student of Bogor Agricultural University \\ ${ }^{2-4)}$ Supervisors, Natural Resources and Environmental Management, Bogor Agricultural University \\ E-mail: melanie.cornelia@uph.edu
}

Received : 22 Maret 2013 ; revised : 12 April 2013; accepted : 29 April 2013

\begin{abstract}
ABSTRAK
Bioplastik adalah plastik yang dapat didegradasi oleh mikroba yang ada di dalam tanah karena adanya kandungan pati di dalamnya. Bioplastik diharapkan merupakan salah satu solusi dari masalah lingkungan yang disebabkan oleh penumpukan sampah kantong plastik belanja yang menjadi beban lingkungan. Secara komersial sudah ada bioplastik yang diproduksi dengan variasi jumlah penambahan pati singkong atau pati jagung, namun kendalanya adalah harga produk masih mahal jika dibandingkan dengan harga kantong plastik konvensional pada umumnya, karena tepung dan pati tersebut masih dibutuhkan di sektor pangan dan energi. Pada penelitian ini bioplastik dibuat dengan menggunakan pati yang diekstraksi dari biji durian yang selama ini merupakan limbah, untuk dicampur dengan biji plastik LDPE pada variasi konsentrasi pati $0 \%$ sampai $50 \%$. Sebagai pembanding dipakai pati dari empulur sagu, sehingga karakteristik fisik seperti warna dan sifat mekanik dari bioplastik seperti kekuatan tarik, perpanjangan putus, dan kekerasan dapat dibandingkan. Uji penurunan berat bioplastik dilakukan dengan pemendaman di dalam tanah selama 8 minggu. Hasil uji Anova menunjukkan perlakuan jenis pati dan konsentrasi pati yang ditambahkan tidak beda nyata $(p>0,05)$ terhadap kehilangan berat plastik. Analisis SEM dilakukan untuk membandingkan rongga diantara molekul pati dengan polimer plastik pada perbesaran $2500 x$ yang menyebabkan kekuatan mekanik plastik menjadi berkurang dan rapuh ketika ditarik. Pati biji durian $10 \%$ terbukti optimal dapat digunakan sebagai substitusi polimer tanpa penambahan aditif dalam pembuatan bioplastik, dengan karakteristik mekanik yang dapat dibandingkan dengan pati sagu dan pati singkong, namun memiliki laju degradasi yang lebih rendah.
\end{abstract}

Kata kunci : Bioplastik, Low density poly ethylene, Pati biji durian, Pati sagu, Kekuatan tarik, Perpanjangan putus

\begin{abstract}
Bioplastics are a plastic that are able to be degradated by microbes in the soil due to its starch content. Bioplastics is expected to be solution of environmental problems caused by the plastic shopping bags waste which became an environmental burden. Commercially, bioplastics already being produced with the variation of percentage cassava or corn starch addition. However the problem regarding such matter is the price of the product is still expensive compared to conventional plastic bags, because the starches are still needed in food and energy sectors. In this study, bioplastic is made from extracted durian seeds starch to be mixed with LDPE plastic ores, with the variation addition of starch concentration by $0 \%$ until $50 \%$. For comparison, starch from sago is used, so that the physical characteristics such as color and mechanical properties such as tensile strength, elongation, and hardness can be compared. Decreasing of bioplastic weight were evaluated with burial in soil for 8 weeks. Anova test results showed that types of starch and percentage of starch are added, give no significant difference $(p>0.05)$ on weight loss of plastic. SEM analysis was conducted to compare the cavity between starch molecules and plastic polymer at 2500x magnification, which causes plastic strength reduced and becomes brittle when being pulled. Addition of $10 \%$ durian seed starch is proven as optimal polymer substitution without additives in making bioplastics, with mechanical characteristics that can be compared with sago and cassava starch, but has a lower degradation rate.
\end{abstract}

Key words : Bioplastic, Durian seeds starch, Elongation, Low density poly ethylene, Sago starch, Tensile strength 


\section{PENDAHULUAN}

Biji plastik merupakan senyawa polimer organik yang berasal dari minyak bumi yang sudah mengalami proses polimerisasi, polikondensasi, dan poliadisi dari monomermonomernya, sehingga dapat dibentuk sesuai dengan bentuk yang diinginkan (Coles et al. 2003). Plastik dipilih sebagai bahan baku kantong belanja karena plastik memiliki banyak kelebihan, diantaranya ringan, relatif murah, fleksibel, tahan terhadap air, dan praktis (Gunawan et al. 2007). Selain memiliki keunggulan, plastik juga memiliki kelemahan, karena bahan baku plastik berasal dari sumber daya yang tak terbarukan dan tidak ramah lingkungan, sehingga limbah plastik sulit sekali terurai oleh mikroorganisme yang akhirnya menimbulkan pencemaran lingkungan (Sanjaya dan Puspita 2012). Manusia berusaha untuk mengatasi pencemaran lingkungan akibat limbah plastik dengan membuat bioplastik (Subowo dan Pujiastuti 2003). Bioplastik adalah plastik yang dibuat dari campuran biji plastik yang dicampur dengan pati jagung, pati tapioka, atau jenis pati yang lain. Bioplastik dalam penelitian ini didefinisikan sebagai plastik yang dibuat dari campuran biji plastik dengan pati dari limbah biji durian agar diperoleh plastik ramah lingkungan yang harga jualnya lebih murah. Selain itu pencampuran antara pati dengan biji plastik juga dapat meningkatkan nilai ekonomis dari pati itu sendiri. Pencampuran antara polimer alami dan polimer sintetis membuat produk yang dihasilkan lebih mudah didegradasi oleh mikroorganisme di dalam tanah. Bioplastik dapat dicetak secara manual menggunakan mesin tekan panas (hot press) atau menggunakan mesin moulding (Subowo dan Pujiastuti 2003). Penelitian tentang bioplastik berkembang sangat pesat di negara-negara maju seperti Amerika Serikat dan Jepang (Sanjaya dan Puspita 2012). Proses degradasi bioplastik dipengaruhi oleh jenis pati yang digunakan, konsentrasi pati yang ditambahkan, dan kondisi lingkungan pemendaman (Syamsu et al. 2008). Pati adalah salah satu polimer alami yang tersusun dari struktur bercabang yang disebut amilopektin dan struktur lurus yang disebut amilosa. Pati dapat diperoleh dengan cara mengekstrak dari tanaman yang kaya akan karbohidrat seperti sagu, singkong, jagung, gandum, dan ubi jalar. Pati juga dapat diekstrak dari biji buah-buahan seperti pada biji nangka, biji alpukat, dan biji durian. Biji durian yang selama ini dianggap limbah oleh manusia karena kurang pemanfaatannya ternyata dapat digunakan sebagai bahan dalam pembuatan bioplastik.
Selain biji durian, empulur tanaman sagu juga dapat digunakan sebagai bahan pembuat bioplastik. Ketersediaan tanaman sagu di Indonesia paling banyak dibandingkan tanaman padi ataupun jagung. Setiap tahun Indonesia mampu menghasilkan sagu sebesar 6,5 juta ton, tetapi pemanfaatan sagu sendiri masih rendah hanya sekitar $6 \%$ dari ketersediaan yang ada (Christianty 2009).

Durian (Durio zibethinus Murr.) adalah buah musiman yang paling populer di Asia Tenggara, khususnya Malaysia, Indonesia, Thailand, dan Filipina (Mirhosseini dan Tabatabaee 2012). Di Indonesia durian merupakan tanaman yang dibudidayakan, durian termasuk familia bombaceae, genus Durio, dan spesies Durio zibethinus Murr. yang tumbuh di daerah tropik (Mirhosseini dan Tabatabaee 2012). Menurut Badan Pusat Statistik Republik Indonesia (2011) menyatakan bahwa produksi durian rata-rata terjadi peningkatan dari 17.405 ton pada tahun 1999 menjadi 741.831 ton pada tahun 2003 dan pada akhir tahun 2011 menjadi 883.969 ton. Pemanfaatan biji durian masih terbatas, karena hanya sepertiga dari buah durian yang bisa dimakan, sedangkan biji $(20 \%$ sampai $25 \%$ ) dan kulit biasanya dibuang. Biji durian memiliki kandungan pati yang cukup tinggi sehingga berpotensi sebagai alternatif pengganti bahan yang memerlukan sifat-sifat pati. Pati merupakan karbohidrat yang berasal dari tanaman sebagai hasil fotosintesis, yang disimpan dalam bagian tertentu tanaman sebagai cadangan makanan. Sifat pati tergantung pada jenis tanaman serta tempat penyimpanannya. Terdapat dua jenis pati yang sering digunakan di industri yaitu pati alami dan pati modifikasi. Pati alami (native starch) adalah pati yang dihasilkan dari sumber umbi-umbian dan belum diolah atau mengalami perubahan sifat fisik dan kimia. Proses pembuatan bioplastik dari pati dapat berlangsung dengan teknik casting atau proses termoplastik (Aguilera et al. 2011).

Tujuan umum dari penelitian ini adalah menghasilkan ekstrak pati biji durian dan membuat bioplastik dengan variasi penambahan masing-masing konsentrasi pati sagu dan pati biji durian. Tujuan khusus penelitian ini adalah mempelajari karakteristik bioplastik yang dibuat dari campuran biji plastik LDPE dengan penambahan pati biji durian dan penambahan pati sagu sebagai pembanding, melihat pengaruh jenis pati, dan variasi konsentrasi pati yang ditambahkan terhadap kualitas fisik, mekanik, dan tingkat degradasi bioplastik. 


\section{BAHAN DAN METODE}

Penelitian ini dilaksanakan selama 7 (tujuh) bulan mulai dari bulan Agustus 2012 sampai dengan bulan Februari 2013 di daerah Karawaci, Tangerang, Propinsi Banten.

\section{Bahan}

Bahan utama yang digunakan yaitu biji durian varietas montong dari penjual durian di Jalan Raya Legok Tangerang, biji plastik LDPE kualitas komersial, dan pati sagu merk "ALINI". Peralatan yang digunakan adalah blender, pisau, gelas ukur, kain saring, oven, loyang, timbangan analitik, mesin rheomix, mesin hot press, dan beaker glass. Peralatan analisis yang digunakan adalah neraca analitik, pot berisi tanah humus, jangka sorong, termometer, higrometer, Material Testing Machine "Lloyd", Texture Analyzer "TA.XT.Plus", dan Scanning Electron Microscope (SEM).

\section{Metode}

Alur kerja penelitian terdiri dari ekstraksi pati biji durian dan pembuatan bioplastik yang dapat dilihat pada Gambar 1 dan Gambar 2.

Perhitungan rendemen dan analisis proksimat seperti kadar air, kadar abu, kandungan protein, kandungan lemak, karbohidrat, dan kadar pati dilakukan terhadap pati biji durian yang dihasilkan. Analisis kadar amilosa dan amilopektin juga dilakukan dalam penelitian ini untuk mendapatkan kualitas pati yang dihasilkan. Analisis yang sama dilakukan terhadap pati sagu yang akan digunakan sebagai bahan untuk mensubstitusi biji plastik LDPE. Selanjutnya masing-masing pati biji durian dan pati sagu dicampur dengan biji plastik LDPE, sesuai dengan perlakuan menjadi poliblend menggunakan mesin Rheomix. Kombinasi perlakuan dalam pembuatan poliblend dapat dilihat pada Tabel 1.

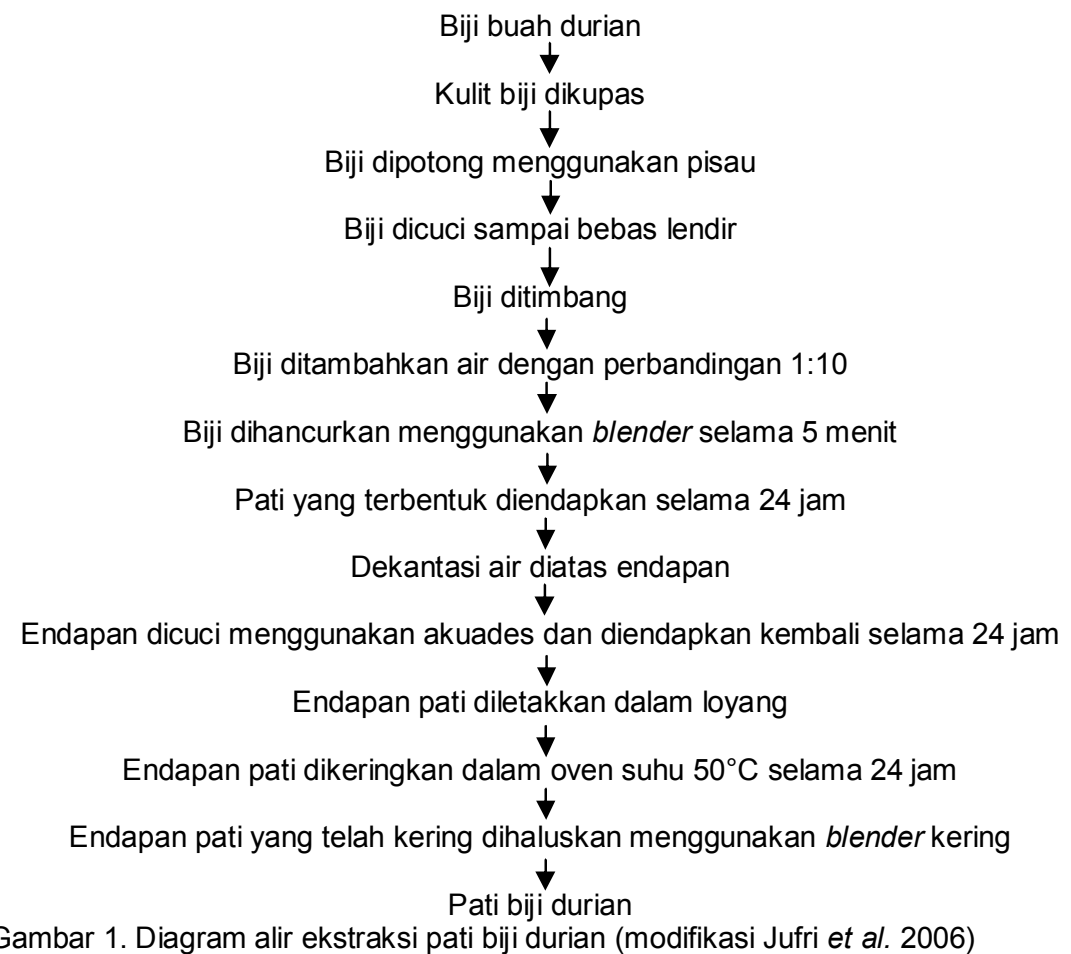

Tabel 1. Kombinasi jenis pati dan variasi konsentrasi pati

\begin{tabular}{cccccc}
\hline \multirow{2}{*}{ Jenis pati } & \multicolumn{3}{c}{ Konsentrasi penambahan pati $(\%)$} & \multirow{2}{*}{ Total perlakuan } \\
\cline { 2 - 5 } & $0 \%$ & $10 \%$ & $30 \%$ & $50 \%$ & $\mathrm{Y}_{.1}$ \\
\hline Biji durian & $\mathrm{Y}_{11}$ & $\mathrm{Y}_{12}$ & $\mathrm{Y}_{13}$ & $\mathrm{Y}_{14}$ & $\mathrm{Y}_{.2}$ \\
Sagu & $\mathrm{Y}_{21}$ & $\mathrm{Y}_{22}$ & $\mathrm{Y}_{23}$ & $\mathrm{Y}_{24}$ & \\
\hline
\end{tabular}




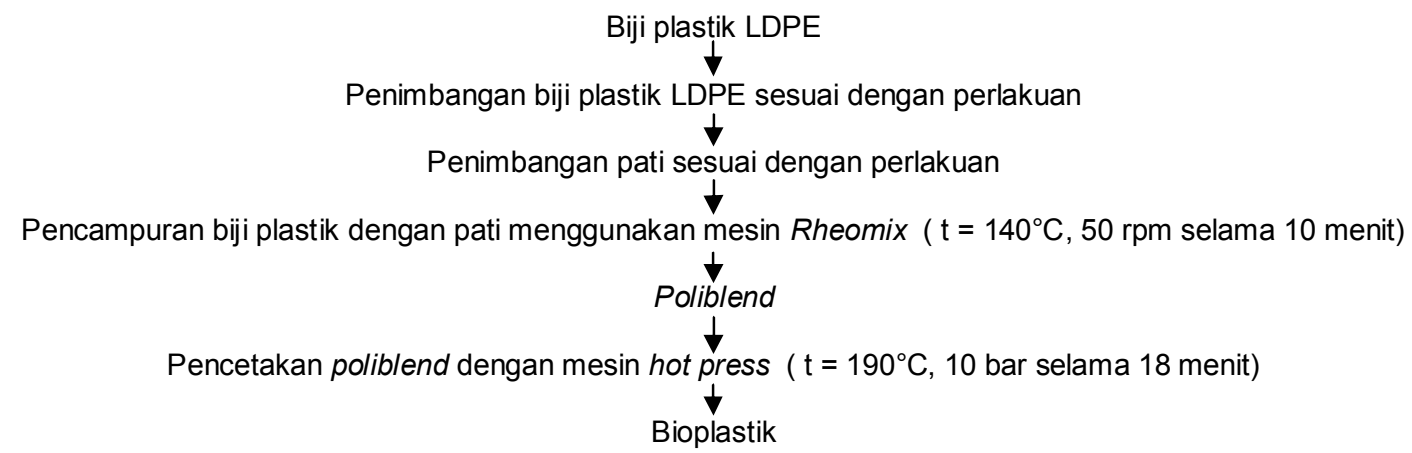

Gambar 2. Diagram alir pembuatan bioplastik (modifikasi Subowo dan Pujiastuti 2003)

Rancangan percobaan adalah Rancangan Acak Lengkap (RAL) dua faktor, yaitu kombinasi jenis pati yang digunakan dan variasi penambahan konsentrasi pati dengan model matematika sebagai berikut:

dimana:

$$
Y_{\mathrm{ij}}=\mu+\alpha_{\mathrm{i}}+\beta_{\mathrm{j}}+(\alpha \beta)_{\mathrm{ij}}+\varepsilon_{\mathrm{ij}}
$$

$\mathrm{Y}_{\mathrm{ij}} \quad$ : kualitas bioplastik dengan menggunakan pati i dan konsentrasi j

$\mu \quad$ : nilai rataan populasi

$\alpha_{i} \quad$ : pengaruh akibat perlakuan sumber pati yang digunakan taraf ke-i

$\beta_{\mathrm{j}} \quad$ : pengaruh akibat konsentrasi pati taraf ke-j

$(\alpha \beta)_{\mathrm{ij}}$ : pengaruh interaksi faktor $\alpha$ taraf ke-i dengan faktor $\beta$ taraf ke-j

$\varepsilon_{\mathrm{ij}} \quad$ : pengaruh galat dari perlakuan ke-i yang memperoleh perlakuan ij

\section{HASIL DAN PEMBAHASAN}

Biji durian memiliki berat minimal 35 gram karena memiliki daging biji yang banyak ketika biji dikupas (Hutapea 2010). Pati hasil ekstraksi biji durian berupa serbuk halus berwarna putih dengan rendemen $19,36 \%$. Komposisi kimia dari pati biji durian dan pati sagu dapat dilihat pada Tabel 2. Adanya protein dalam pati durian yang cukup tinggi dapat menginduksi terjadinya reaksi pencoklatan sehingga bioplastik yang terbuat dari pati durian warnanya lebih gelap dari bioplastik yang terbuat dari pati sagu.
Pati disusun oleh molekul yang lurus (amilosa) yang membuat pati membentuk gel ketika dipanaskan dan molekul yang bercabang (amilopektin) yang membuat pati memiliki sifat lengket. Rasio amilosa dan amilopektin bervariasi untuk setiap jenis pati. Pati tapioka memiliki rasio amilosa dan amilopektin 15:69; pati kentang 21:79; sedangkan pati sagu 23:63 (Tongdang 2008). Pati biji durian hasil ekstraksi memiliki rasio 14:74 yang hampir sama dengan pati tapioka, sehingga memungkinkan untuk dijadikan bahan baku dalam pembuatan plastik biodegradable (bioplastik). Pati memiliki ikatan asetal yang mudah sekali untuk diuraikan oleh mikroorganisme. Kelemahan dari komposit polietilena-pati adalah penambahan pati dapat menurunkan kekuatan tarik dari komposit polietilena-pati (Gunawan et al. 2008).

\section{Pembuatan Bioplastik-LDPE (Low Density Poly Ethylene)}

Pembuatan bioplastik dari campuran pati biji durian dengan biji plastik LDPE dan juga pati sagu dengan biji plastik LDPE sesuai dengan diagram alir pada Gambar 2, dengan variasi konsentrasi pati $0 \%$ sampai $50 \%$. Penambahan pati untuk pembuatan bioplastik bisa dilakukan mulai dari pati $15 \%$ sampai $80 \%$ (Chinnaswamy dan Hanna 1996). Pati sagu, pati biji durian, dan biji plastik LDPE sulit untuk bercampur secara manual pada suhu ruang karena perbedaan

Tabel 2. Analisis kimia pati biji durian dan pati sagu

\begin{tabular}{|c|c|c|c|}
\hline Analisis & Pati biji durian & Pati sagu & Pati singkong **) \\
\hline Karbohidrat (\%) & 83,92 & 88,94 & 93,33 \\
\hline Rasio amilosa/amilopektin & $14 / 74$ & $23 / 63$ & $15 / 69$ \\
\hline Protein (\%) & 4,76 & 0,35 & - \\
\hline Lemak (\%) & 0,38 & 0,04 & - \\
\hline Abu $(\%)$ & 0,25 & 0,26 & 0,06 \\
\hline Air (\%) & 10,71 & 10,34 & 8,62 \\
\hline Granula pati " & $8 \mu \mathrm{m}$ sampai $10 \mu \mathrm{m}$ & $20 \mu \mathrm{m}$ sampai $60 \mu \mathrm{m}$ & - \\
\hline
\end{tabular}


polaritas antara pati sagu dan pati biji durian yang bersifat polar, sedangkan biji plastik $L D P E$ bersifat non polar. Pada penelitian ini pencampuran antara pati dan biji plastik $\angle D P E$ dilakukan menggunakan alat rheomix dengan suhu $140^{\circ} \mathrm{C}$ dan kecepatan putar motor $50 \mathrm{rpm}$ selama 10 menit.

Hasil pencampuran biji plastik dengan pati disebut poliblend (Subowo dan Pujiastuti 2003) yang ukurannya akan diperkecil menjadi bentuk pelet. Ada empat komposisi pencampuran pati dan biji plastik LDPE yang dipakai dalam pembuatan poliblend, baik untuk pati sagu maupun pati biji durian (Tabel 1), yaitu \%pati : \%LDPE adalah 0:100; 10:90; 30:70; dan 50:50. Selanjutnya poliblend dicetak menggunakan mesin hot press pada suhu $190^{\circ} \mathrm{C}$, tekanan 10 bar, selama 18 menit, dan dihasilkan lembaran bioplastik dengan diameter $20 \mathrm{~cm}$ dan ketebalan $0,79 \mathrm{~cm}$. Hasil cetakan poliblend durian (D) dan sagu (S) dapat dilihat pada Gambar 3. Terlihat bahwa poliblend yang dibuat dari pati biji durian memiliki warna yang lebih coklat daripada poliblend yang dibuat dari pati sagu, baik dalam penambahan $10 \%$, 30\%, dan $50 \%$.

\section{Hasil Uji Warna dan Uji Pendam Bioplastik}

Bioplastik yang dihasilkan diukur indeks putihnya menggunakan kromameter dan diperoleh hasil dengan rentang nilai indeks putih berkisar 7,66 sampai 98,36 (rentang warna coklat sampai ke warna putih). Tingkat indeks putih dapat dilihat pada Gambar 4. Tujuan uji warna adalah untuk melihat rentang indeks dari bioplastik yang dihasilkan. Perlakuan jenis pati dan variasi konsentrasi pati serta interaksi antara jenis dan konsentrasi pati berpengaruh nyata $(p<0,05)$ terhadap indeks putih bioplastik (hasil uji Anova). Hasil uji lanjut dengan metode Tukey HSD menunjukkan indeks putih bioplastik pati biji durian berbeda nyata dengan indeks putih bioplastik pati sagu pada perlakuan yang sama. Bioplastik pati biji durian memiliki warna yang lebih coklat dari bioplastik pati sagu karena pati biji durian yang dipakai belum mengalami proses bleaching dan pemurnian (ditunjukkan dengan adanya kandungan protein yang tinggi pada pati). Adanya protein ini dapat memicu terjadinya reaksi maillard (Tongdang 2008). Sedangkan pati sagu yang digunakan dalam penelitian ini adalah pati sagu komersial yang telah mengalami proses bleaching dan pemurnian, sehingga warna bioplastik yang dihasilkan lebih cerah. Penurunan berat merupakan salah satu indikasi terjadinya proses degradasi bioplastik yang dinyatakan dalam persen kehilangan berat selama dipendam dalam tanah. Pada penelitian ini bioplastik dipendam dalam tanah yang telah diletakkan dalam pot selama 8 minggu dengan kedalaman $10 \mathrm{~cm}$ dari permukaan tanah. Pot diletakkan di laboratorium agar suhu dan kelembaban tanah dapat dikontrol. Bioplastik yang dipendam ditimbang setiap minggu untuk diketahui perubahan beratnya. Selama pemendaman bioplastik tidak mengalami perubahan warna yang menunjukkan bahwa tidak terjadi reaksi kimia (Aidzan 2009).

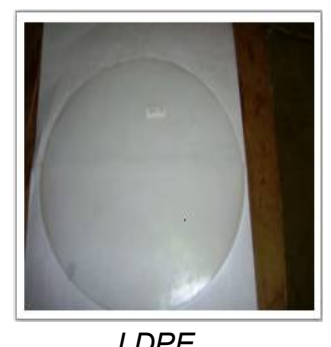

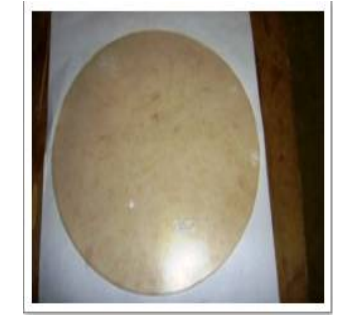

LDPE-D10\%

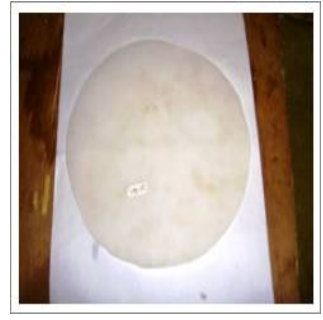

LDPE-S10\%

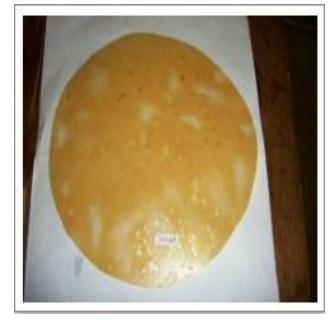

LDPE-D30\%

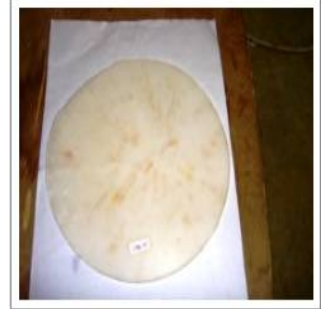

LDPE-S30\%

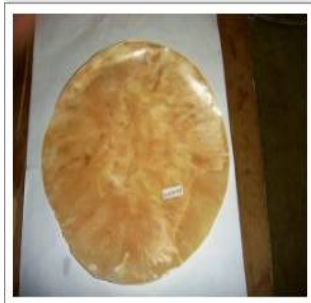

LDPE-D50\%

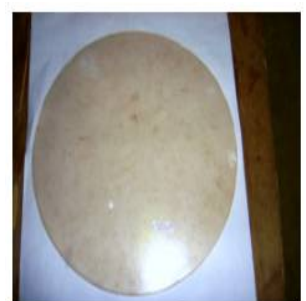

LDPE-S50\%

Gambar 3. Poliblend bioplastik (sumber: dokumentasi pribadi) 
Jenis dan variasi konsentrasi pati tidak berpengaruh nyata $(p>0,05)$ terhadap kehilangan berat, artinya persen penurunan berat bioplastik pati biji durian tidak berbeda nyata dibandingkan dengan bioplastik pati sagu (Gambar 5). Uji mikrobiologi menunjukkan bahwa jumlah mikroba yang ada di dalam tanah semakin bertambah. Spesies-spesies dominan yang terdapat pada polietilena adalah Bacillus sp., Staphylococcus sp., Streptococcus sp., Pseudomonas sp., Moraxella sp., Aspergillus niger, dan $A$. flavus. Mikroba-mikroba tersebut umumnya terdapat pada permukaan plastik polietilena dan memanfaatkan polietilena sebagai sumber karbon untuk metabolisme mereka (Vijaya dan Reddy 2008).

\section{Hasil Uji Kekuatan Mekanik Bioplastik}

Uji kuat tarik, uji perpanjangan putus, dan modulus elastisitas (modulus Young) dilakukan dengan menggunakan Mat.Testing Machine, sedangkan kekerasan bioplastik dengan menggunakan Texture Analyzer TAT/X2. Modulus Young adalah perbandingan besaran kekuatan tarik dan perpanjangan putus. Modulus Young berkaitan dengan nilai elastisitas dari bioplastik (Askeland et al. 2010), makin banyak pati yang ditambahkan akan membuat modulus Young bioplastik menjadi berkurang.

Gambar 6 dan 7 menunjukkan bahwa bioplastik pati sagu memiliki nilai kekuatan tarik dan kekerasan yang lebih tinggi dibandingkan dengan bioplastik pati biji durian. Ini disebabkan

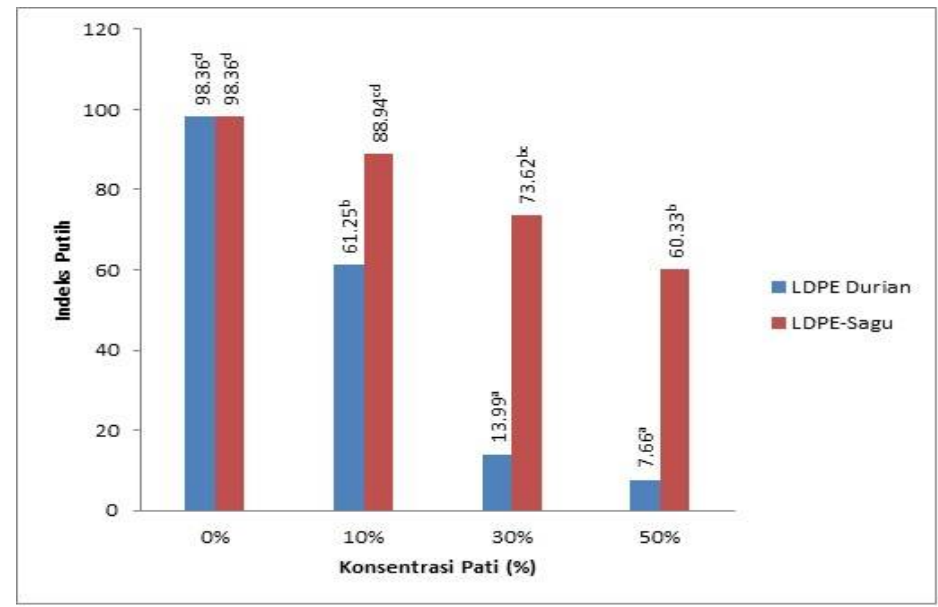

Gambar 4. Grafik indeks putih bioplastik

Keterangan: notasi huruf yang berbeda di belakang angka menunjukkan beda nyata $(p<0,05)$
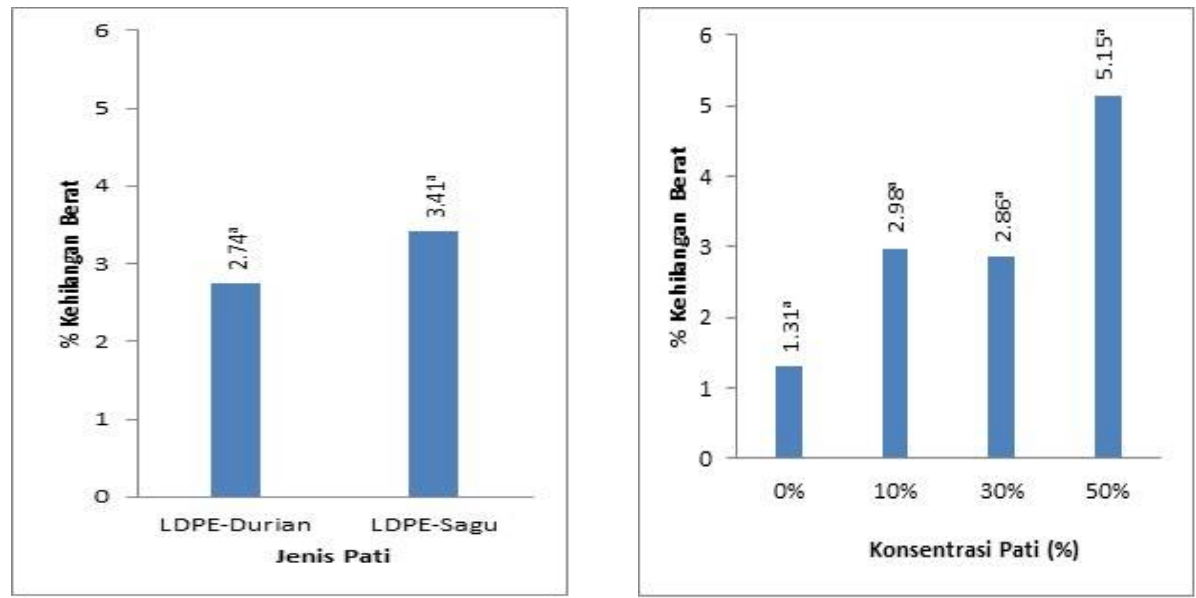

Gambar 5. Grafik persen kehilangan berat selama uji pendam

Keterangan: notasi huruf yang berbeda di belakang angka menunjukkan beda nyata $(p<0,05)$ 

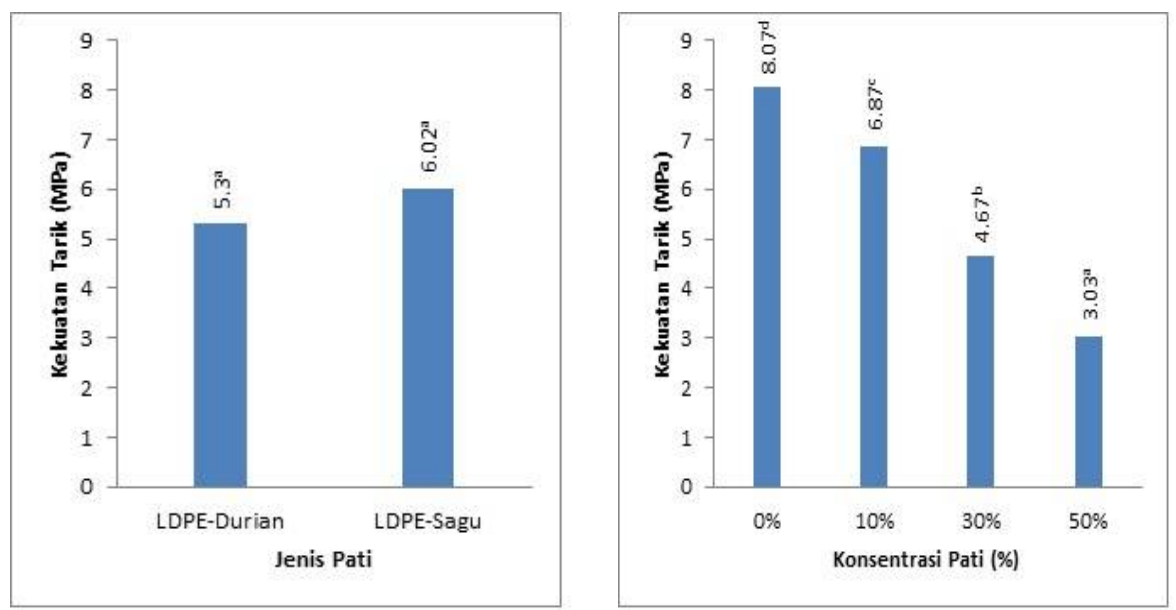

Gambar 6. Kekuatan tarik terhadap jenis pati

Keterangan: notasi huruf yang berbeda di belakang angka menunjukkan beda nyata $(p<0,05)$
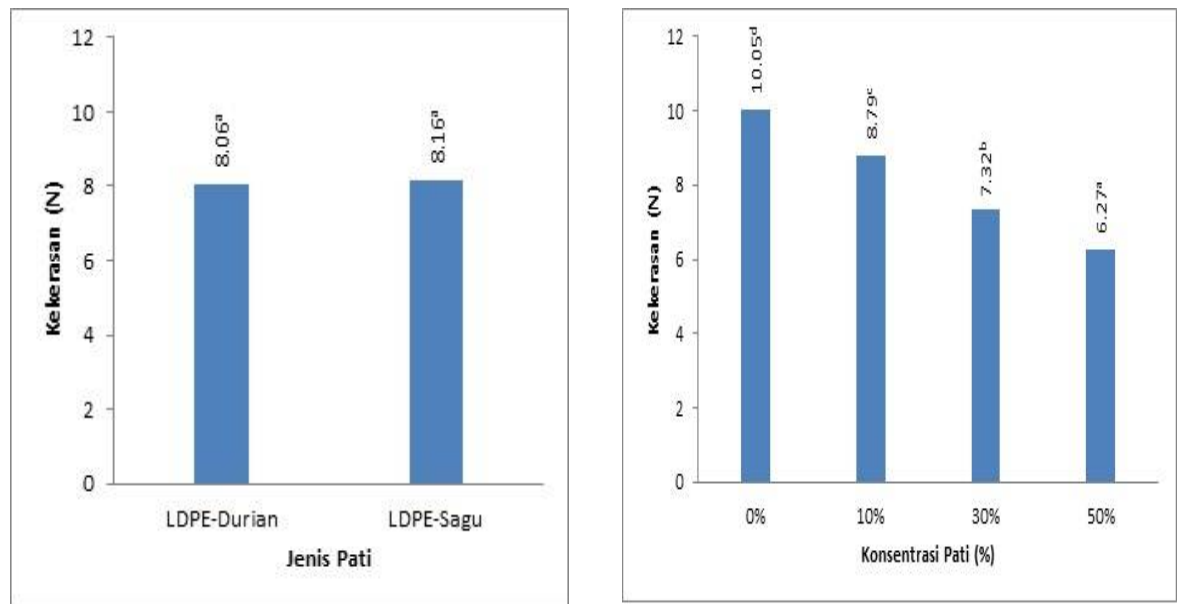

Gambar 7. Kekerasan terhadap jenis pati

Keterangan: notasi huruf yang berbeda di belakang angka menunjukkan beda nyata $(p<0,05)$

pati sagu memiliki ukuran granula pati lebih besar, sehingga memiliki gaya adhesi antara pati dan polimer yang kuat sehingga nilai kekuatan tariknya besar (Moura 2006). Data penelitian penambahan pati singkong $15 \%$ dalam pembuatan bioplastik menyebabkan penurunan kekuatan tarik sebesar 37,3\% dibandingkan dengan resin LLDPE murni (Theresia 2003). Makin tinggi persen pati yang ditambahkan maka kompatibilitas campuran berkurang, terjadi pelemahan gaya adhesi antara molekul pati dengan molekul plastik sehingga plastik berubah menjadi rapuh dan keelastisitasan bioplastik berkurang. Penambahan komponen pati diatas $20 \%$ membuat plastik menjadi rapuh (Aidzan et al. 2009).
Gambar 8 menunjukkan jenis pati dan variasi konsentrasi pati berpengaruh nyata $(p<0,05)$ terhadap perpanjangan putus bioplastik. Interaksi antara jenis pati dan variasi konsentrasi pati berpengaruh nyata $(p<0,05)$ terhadap perpanjangan putus bioplastik. Hasil uji lanjut dengan metode Tukey HSD menunjukkan bahwa perpanjangan putus pada perlakuan LDPE-pati biji durian konsentrasi $30 \%$ dan $50 \%$ berbeda dengan perlakuan LDPE-pati sagu konsentrasi $10 \%$ serta berbeda dengan konsentrasi $0 \%$.

Gambar 9 menunjukkan modulus Young bioplastik pati sagu lebih besar daripada bioplastik pati durian. Menurut Moura (2006) bioplastik pati sagu (granula pati besar) memiliki kekuatan tarik dan regangan tarik yang lebih 


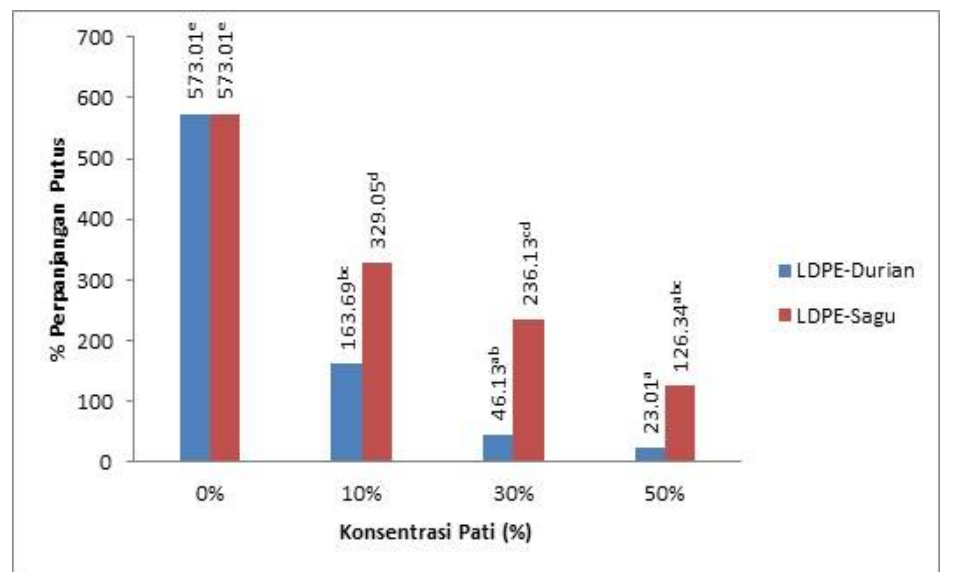

Gambar 8. Persen perpanjangan putus terhadap jenis dan konsentrasi pati

Keterangan : notasi huruf yang berbeda di belakang angka menunjukkan beda nyata $(p<0,05)$
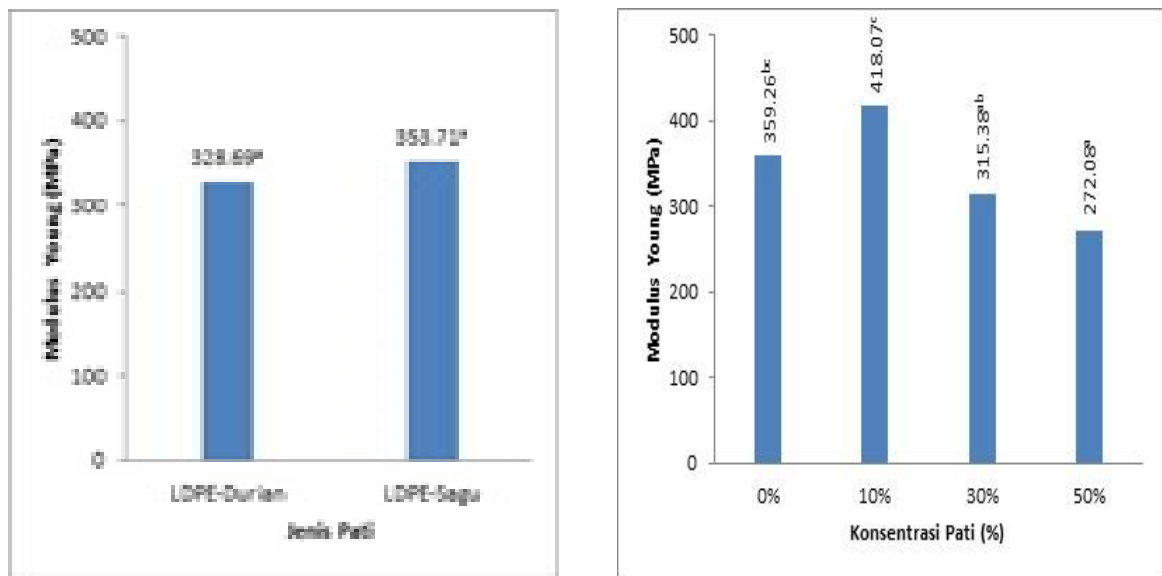

Gambar 9. Modulus Young terhadap jenis dan konsentrasi pati

Keterangan : notasi huruf yang berbeda di belakang angka menunjukkan beda nyata $(p<0,05)$

tinggi daripada bioplastik pati biji durian. Karena modulus Young dipengaruhi oleh kekuatan tarik dan regangan tarik, maka semakin besar nilai kekuatan tarik dan regangan tarik maka modulus Young semakin besar dan benda semakin elastis. Jenis pati tidak berpengaruh nyata $(p>0,05)$ terhadap modulus Young, namun variasi konsentrasi pati berpengaruh nyata $(p<0,05)$. Interaksi tidak berpengaruh nyata $(p>0,05)$ terhadap modulus Young dari bioplastik. Hasil uji lanjut dengan metode Tukey HSD menunjukkan bahwa modulus Young bioplastik pada konsentrasi pati $10 \%$ berbeda dengan perlakuan konsentrasi pati $50 \%$.

\section{Analisis SEM}

Struktur morfologi bioplastik dianalisis menggunakan SEM. Hasil analisis SEM dengan perbesaran 2500x (Gambar 10) menunjukkan bahwa penyebaran granula pati meningkat seiring dengan tingginya konsentrasi pati dalam campuran. Hasil analisis SEM menunjukkan bahwa semakin tinggi persen pati ditambahkan, semakin banyak penyebaran granula pati di dalam polimer plastik. Terlihat pencampuran merata (Gambar 10c dan 10d) pada penambahan pati durian dan pati sagu $10 \%$, berbeda dengan Gambar $10 \mathrm{e}$ dan $10 \mathrm{f}$ penambahan pati $50 \%$. Penambahan pati $10 \%$ dianggap merupakan konsentrasi yang optimal pada pembuatan bioplastik tanpa penambahan zat aditif. Adanya rongga di antara molekul pati dengan polimer plastik ditunjukkan pada perbesaran 2500x. Celah ini yang menyebabkan kekuatan mekanik plastik menjadi berkurang karena membuat plastik menjadi rapuh ketika ditarik (Aht-Ong dan Charoenkungthum 2002). 


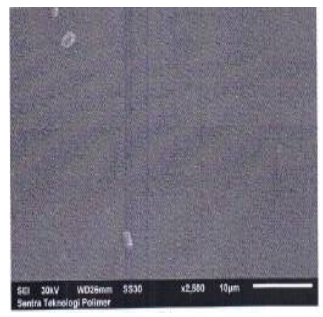

(a) $L D P E$

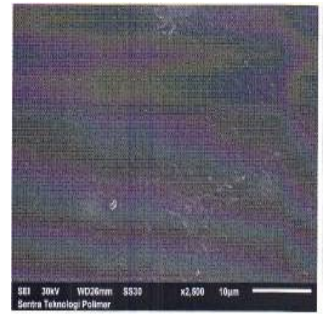

(d) LDPE-S10\%

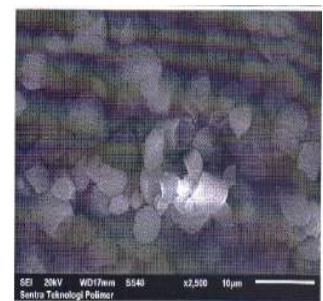

(b) Pati biji durian

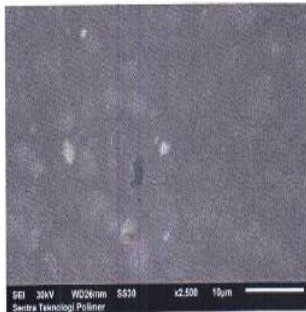

(e) LDPE-D50\%

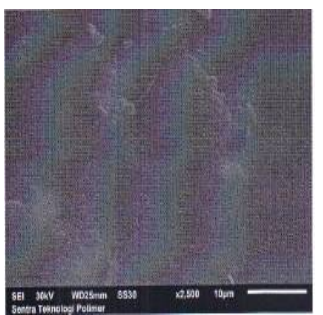

(c) $L D P E-D 10 \%$

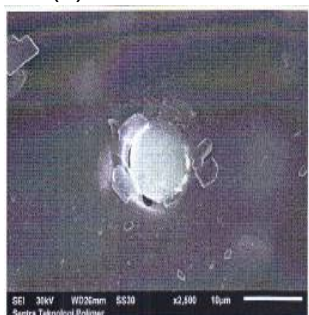

(f) $L D P E-S 50 \%$

Gambar 10. Struktur morfologi LDPE, pati biji durian, dan bioplastik

\section{KESIMPULAN}

Pati yang diperoleh dari ekstrak biji durian menggunakan pelarut air, berpotensi, dan dapat dimanfaatkan sebagai campuran bahan untuk membuat bioplastik yaitu plastik ramah lingkungan (biodegradable). Karakteristik mekanik bioplastik yang dihasilkannya hampir sama dengan bioplastik dari pati sagu dan pati singkong. Penampakan fisik bioplastik yang terbuat dari pati biji durian terlihat lebih gelap daripada bioplastik yang terbuat dari pati sagu karena adanya protein dalam pati biji durian cukup tinggi yang dapat menginduksi terjadinya reaksi pencoklatan. Bioplastik pati biji durian dan bioplastik pati sagu yang dipendam dalam tanah akan mengalami pengurangan berat akibat terjadi proses degradasi oleh mikroba di dalam tanah, namun keduanya tidak berbeda nyata. Potensi pati ini diharapkan dapat dipakai untuk membuat kantong plastik belanja ramah lingkungan sehingga produknya dapat dijual dengan harga yang lebih murah, karena pati biji durian merupakan limbah namun keberadaannya juga mudah diperoleh. Kantong plastik ramah lingkungan dengan memakai pati dari limbah biji-bijian diharapkan dapat diproduksi skala industri, agar masyarakat mulai tertarik menggunakan kantong plastik belanja jenis ini, sehingga dampak negatif sampah kantong plastik belanja terhadap lingkungan dapat diminimalisasi.

\section{DAFTAR PUSTAKA}

Aguilera, J. M., R. Simpson, J. W. Chanes, D. B. Aguirre. 2011. Food engineering intefaces. New York: Springer.

Aht-Ong, D. dan K. Charoenkongthum. 2002. Thermal properties and moisture absorption of LDPE/banana starch biocomposite films. Journal of Metal, Material, and Minerals. 12(1): 1-10.

Aidzan, W., R. A. Ali, J. Jamaluddin, dan I. I. Mohammad. 2009. Development of polyethylene sago based biofilm via blown film molding technique. Faculty of Chemical and Natural Resources. Malaysia.

Askeland, D. R., P. P. Fulay, dan W. J. Wright. 2010. The science and engineering of materials 6th edition. USA: Cengange Learning.

Badan Pusat Stastistik (BPS). 2011. Produksi buah-buahan menurut provinsi (ton). Jakarta.

Chinnaswamy, R. dan M. A. Hanna. 1996. Biodegradable polymer. USA.

Christianty, M.U. 2009 .Produksi biodegradable plastic melalui pencampuran pati sagu termoplastis dan compatibilized linear low density polyethylene. Tesis. Bogor: Institut Pertanian Bogor.

Coles, R., D. McDowel, dan M. J. Kirwan. 2003. Food packaging technology. lowa: Blackwell Publishing.

Gunawan, I., Deswita, Aloma, dan Sudirman. 2007. Modifikasi polyethylene sebagai polimer komposit biodegradable untuk bahan kemasan. Jurnal Sains Materi Indonesia (edisi khusus): 37-42.

Gunawan, I., Deswita, Aloma, dan Sudirman. 2008. Sintesis dan karakterisasi komposit high density polyethylenepati tapioka. Jurnal Sains Materi Indonesia (1): 5-8.

Hutapea, P. 2010. Pembuatan tepung biji durian (Durio Zibethinus Murr) dengan variasi perendaman dalam air kapur dan uji 
mutunya. Tesis. Medan: Universitas Sumatera Utara.

Jufri, M., R. Dewi, A. Ridwan, dan Firli. 2006. Studi kemampuan pati biji durian sebagai bahan pengikat dalam tablet ketoprofen secara granulasi basah. Majalah IImu Kefarmasian 3(2): 78-86.

Mirhosseini, H., and Tabatabaee Amid, B. 2012. A review study on chemical composition and molecular structure of newly plant gum exudates and seed gums. Food Res. Int. (46): 387-398.

Moura, R. A. 2006 .The effect of physical aging, starch particle size, and starch oxidation on thermal-mechanical properties of poly (lactic acid)/starch composites. An abstract of a Dissertation

Sanjaya, I. G. dan T. Puspita. 2012. Pengaruh penambahan khitosan dan plasticizer glicerol pada karakteristik plastik biodegradable dari pati limbah kulit singkong. Tesis. Surabaya: Institut Teknologi Sepuluh November.

Soebagio, B., Sriwidodo, dan A. Aditya. 2009. Pengujian sifat fisikokimia pati biji durian (Durio zibethinus Murr) alami dan modifikasi secara hidrolisa asam. Tesis. Bandung

UniversitasPadjajaran.

Subowo, W. S. dan S. Pujiastuti. 2003. Plastik yang terdegradasi secara alami (biodegradable) terbuat dari LDPE dan pati jagung terlapis. Journal of Applied Polymer Science (42): 2691-2701.

Syamsu, K., K. Setyowati, dan A. A. Khoiri. 2008. Pengaruh penambahan pemlastis (polietilen glikol 400, dietilen glikol, dan dimetil ftalat) terhadap proses biodegradasi bioplastik poli $\beta$ hidroksialkanoat pada media cair dengan udara terlimitasi. Jurnal Teknologi Pertanian 4(1): 1-11.

Theresia, V. 2003. Aplikasi dan karakterisasi sifat fisik-mekanik plastik biodegradable dari campuran LLDPE dan tapioka. Tesis. Bogor : Institut Pertanian Bogor.

Tongdang, T. 2008. Some properties of starch extracted from three thai aromatic fruit seeds. Journal of Starch 60(3-4): 199207.

Vijaya, C. dan R. M. Reddy. 2008. Impact of soil composting using municipal solid waste biodegradation of plastics. Indian Journal of Biotechnology (7): 235-239. 